\title{
Is the United States Bankrupt?
}

\author{
Laurence J. Kotlikoff
}

\begin{abstract}
Is the United States bankrupt? Many would scoff at this notion. Others would argue that financial implosion is just around the corner. This paper explores these views from both partial and general equilibrium perspectives. It concludes that countries can go broke, that the United States is going broke, that remaining open to foreign investment can help stave off bankruptcy, but that radical reform of U.S. fiscal institutions is essential to secure the nation's economic future. The paper offers three policies to eliminate the nation's enormous fiscal gap and avert bankruptcy: a retail sales tax, personalized Social Security, and a globally budgeted universal healthcare system.
\end{abstract}

Federal Reserve Bank of St. Louis Review, July/August 2006, 88(4), pp. 235-49.

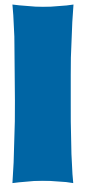

s the U.S. bankrupt? Or to paraphrase the Oxford English Dictionary, is the United States at the end of its resources, exhausted, stripped bear, destitute, bereft, wanting in property, or wrecked in consequence of failure to pay its creditors?

Many would scoff at this notion. They'd point out that the country has never defaulted on its debt; that its debt-to-GDP (gross domestic product) ratio is substantially lower than that of Japan and other developed countries; that its long-term nominal interest rates are historically low; that the dollar is the world's reserve currency; and that China, Japan, and other countries have an insatiable demand for U.S. Treasuries.

Others would argue that the official debt reflects nomenclature, not fiscal fundamentals; that the sum total of official and unofficial liabilities is massive; that federal discretionary spending and medical expenditures are exploding; that the United States has a history of defaulting on its official debt via inflation; that the government has cut taxes well below the bone; that countries holding U.S. bonds can sell them in a nanosecond; that the financial markets have a long and impressive record of mispricing securities; and that financial implosion is just around the corner.

This paper explores these views from both partial and general equilibrium perspectives. The second section begins with a simple two-period life-cycle model to explicate the economic meaning of national bankruptcy and to clarify why government debt per se bears no connection to a country's fiscal condition. The third section turns to economic measures of national insolvency, namely, measures of the fiscal gap and generational imbalance. This partial-equilibrium analysis strongly suggests that the U.S. government is, indeed, bankrupt, insofar as it will be unable to pay its creditors, who, in this context, are current and future generations to whom it has explicitly or implicitly promised future net payments of various kinds.

The world, of course, is full of uncertainty. The fourth section considers how uncertainty changes one's perspective on national insolvency and methods of measuring a country's long-term fiscal condition. The fifth section asks whether immigration or productivity improvements arising either from technological progress or capital

Laurence J. Kotlikoff is a professor of economics at Boston University and a research associate at the National Bureau of Economic Research.

(C) 2006, The Federal Reserve Bank of St. Louis. Articles may be reprinted, reproduced, published, distributed, displayed, and transmitted in their entirety if copyright notice, author name(s), and full citation are included. Abstracts, synopses, and other derivative works may be made only with prior written permission of the Federal Reserve Bank of St. Louis. 
deepening can ameliorate the U.S. fiscal condition. While immigration shows little promise, productivity improvements can help, provided the government uses higher productivity growth as an opportunity to outgrow its fiscal problems rather than perpetuate them by effectively indexing expenditure levels to the level of productivity.

We certainly have seen major changes in technology in recent decades, and these changes have coincided with major increases in measured productivity. But whether or not technology will continue to advance is an open question. There is, however, a second source of productivity improvements, namely, a rise in capital per worker (capital deepening), to consider. The developed world is not saving enough and will not be saving enough to generate capital deepening on its own. However, China is saving and growing at such extraordinarily high rates that it can potentially supply the United States, the European Union, and Japan with huge quantities of capital. This message is delivered in Fehr, Jokisch, and Kotlikoff (2005), which simulates the dynamic transition path of the United States, Japan, the European Union, and China. Their model suggests that China can serve as America's saver and, consequently, savior, provided the U.S. government lets growth outpace its spending and provided China is permitted to invest massive sums in our country. Unfortunately, recent experience suggests just the opposite.

The final section offers three radical policies to eliminate the nation's enormous fiscal gap and avert bankruptcy. These policies would replace the current tax system with a retail sales tax, personalize Social Security, and move to a globally budgeted universal healthcare system implemented via individual-specific health-insurance vouchers. The radical stance of these proposals reflects the critical nature of our time. Unless the United States moves quickly to fundamentally change and restrain its fiscal behavior, its bankruptcy will become a foregone conclusion.

\section{FISCAL INSOLVENCY IN A TWO-PERIOD LIFE-CYCLE MODEL}

Consider a model in which a single goodcorn-is produced with labor and capital in either an open or closed economy. Corn can be either consumed or used as capital (planted to produce more corn). Agents work full time when young and consume when old. There is no change over time in either population or technology. The population of each cohort is normalized to 1.

Let $w_{t}$ stand for the wage earned when young by the generation born in year $t, r_{t}$ for the return on capital at time $t$, and $h_{t}$ for the amount the government receives from the young and hands to the old at time $t$.

The generation born at time $t$ maximizes its consumption when old, $c_{t}+1$, subject to

$$
\frac{c_{t+1}}{1+r_{t+1}} \leq w_{t}-h_{t}+\frac{h_{t+1}}{1+r_{t+1}} \text {. }
$$

If the economy of this country, called Country X, is open and agents are free to borrow, $h_{t}$ can exceed $w_{t}$. However, consumption can't be negative, hence,

$$
h_{t}-\frac{h_{t+1}}{1+r_{t+1}} \leq w_{t} .
$$

The left-hand side of (2) is generation t's remaining (in this case, entire) lifetime fiscal burdenits generational account. Equation (2) says that the government can't extract more from a generation than its lifetime resources, which, in this model, consists simply of lifetime earnings.

Suppose that, to keep things simple, the economy is small and open and that the wage and interest rates are positive constants equal to $w$ and $r$, respectively. Also suppose that starting at some time, say 0 , the government announces a policy of setting $h_{t}$ equal to $h$ forever and that

$$
h_{t}-\frac{h}{1+r}>w
$$

meaning that the generational accounts of all generations starting with the one born at time 0 exceed their lifetime resources.

The old at time 0 have a generational account (remaining lifetime fiscal burden) of $-h$. These oldsters, who may have voted for the government based on the promise of receiving $h$, represent the creditors in this context. But the government can't deliver on its promise. The young may be fanatically devoted to the government, worship the 
elderly, and care little for themselves, but they cannot beg, borrow, or steal this much corn to give to the government. The government can go hat in hand to foreign lenders, but to no avail. Foreign lenders will realize the government won't be able to repay.

The most the government can do for the elderly is to set $h$ equal to $(1+r) w / r$. Let's assume the government does this. In this case, the government impoverishes each generation of young from time 0 onward in order to satisfy the claims of time-0 oldsters. In the words of the Oxford English Dictionary, we have a country at the end of its resources. It's exhausted, stripped bear, destitute, bereft, wanting in property, and wrecked (at least in terms of its consumption and borrowing capacity) in consequence of failure to pay its creditors. In short, the country is bankrupt and is forced to reorganize its operations by paying its creditors (the oldsters) less than they were promised.

\section{Facing the Music}

The point at which a country goes bankrupt depends, in general, on its technology and preferences as well as its openness to international trade. If, for example, agents who face confiscatory lifetime fiscal burdens refuse to work, there will be no lifetime resources for the government to appropriate. Consequently, the government must further limit what it can pay its creditors.

As a second example, consider what happens when an open economy, which has been transferring $(1+r) w / r$ to the elderly on an ongoing basis, suddenly, at time 0 , becomes closed to international trade and credit. In this case, the government can no longer pay the contemporaneous elderly the present value of the resources of all current and future workers. Instead, the most it can pay the time-t elderly is the current young's resources, namely $w_{t}$. The reason is simple. The time- $t$ young have no access to foreign loans, so they can't borrow against their future receipt of $h$ in order to hand the government more at time $t$ than $w_{t}$.

Clearly the loss of foreign credit will require the government to renege on much of its commitment to the time- $t$ oldsters. And if the government was initially setting $h$ below $(1+r) w / r$, but above $w_{t}$, the inability to borrow abroad will plunge the country into bankruptcy, assuming the government sets $h$ as high as possible. But bankruptcy may arise over time even if $h$ is set below $w_{0}$. To see this, note that capital per worker at time $1, k_{1}$, will equal $w_{0}-h$. If $w\left(k_{1}\right)<w_{0}$, where $w\left(k_{t}\right)$ (with $\left.w^{\prime}()>0\right)$ references the wages of generation $t$, the country will find itself in a death spiral for sufficiently high values of $h$ or sufficiently low values of $w_{0} \cdot{ }^{1}$ Each period's capital stock will be smaller than the previous period's until $t^{*}$, where $h \geq w_{t}^{*}$, making $k_{t^{*}+1}=0$, at which point the jig is up, assuming capital as well as labor is required to produce output.

In short, general equilibrium matters. A policy that looks sustainable based on current conditions may drive a country broke and do so on a permanent basis. Of course, policymakers may adjust their policies as they see their country's output decline. But they may adjust too little or too late and either continue to lose ground or stabilize their economies at very unpleasant steady states. Think of Argentina, which has existed in a state of actual or near-bankruptcy for well neigh a century. Argentina remains in this sorry state for a good reason. Its creditors-primarily each successive generation of elderly citizens-force the government to retain precisely those policies that perpetuate the country's destitution.

\section{Does Official Debt Record or Presage National Bankruptcy?}

Since general equilibrium considerations play a potentially critical role in assessing policy sustainability and the likelihood of national bankruptcy, one would expect governments to be hard at work developing such models or, at a minimum, doing generational accounting to see the potential burden facing current young and future generations. That's not the case. Instead, governments

1 If $h$ is sufficiently large, there will be no steady state of the economy featuring a positive capital stock. In this case, the economy's capital stock will converge to zero over time, starting from any initial value of capital. If $h$ is not so large as to preclude a steady state with positive capital, the economy will feature two steady states, one stable and one unstable. The capital stock in the stable steady state will exceed that in the unstable steady state. In this case, the economy will experience a death spiral only if its initial capital stock is less than that in the unstable steady state. 
around the world rely on official debt as the primary indicator of fiscal solvency. So do the International Monetary Fund, World Bank, Organisation for Economic Co-operation and Development, and virtually all other monitors of economic policy, including most academic economists.

Unfortunately, the focus on government debt has no more scientific basis than reading tea leaves or examining entrails. To see this, let's return to our small open and entirely bankrupt Country X, which, when we left it, was setting $h$ at the maximally expropriating value of $(1+r) w / r$. Can we use Country X's debt to discern its insolvency?

Good question, particularly because the word "debt” wasn't used at all in describing Country X's fiscal affairs. Neither, for that matter, were the words "taxes" or "transfer payments." This, by itself, indicates the value of "debt" as a precursor or cursor of bankruptcy, namely, zero. But to drive the point home, suppose Country X calls the $h$ it takes from the young each period a "tax" and the " $h$ " it gives to the old each period a "transfer payment.” In this case, Country X never runs a deficit, never has an epsilon worth of outstanding debt, and never defaults on debt. Even though it is as broke as broke can be, Country X can hold itself out as debt-free and a model of fiscal prudence.

Alternatively, let's assume the government continues to call the $h$ it gives the time-0 elderly a transfer payment, but that it calls the $h$ it takes from the young in periods $t \geq 0$ "borrowing of $m_{t} h$ less a transfer payment of $\left(m_{t}-1\right) h$ " and the $h$ it gives generation $t$ when it is old at time $t+1$ "repayment of principal plus interest in the amount of $m_{t} h(1+r)$ less a net tax payment of $-h+m_{t} h(1+r)$." Note that no one's generational account is affected by the choice of language. However, the outstanding stock of debt at the end of each period $t$ is now $m_{t} h$.

The values of $m_{t}$ can be anything the government wants them to be. In particular, the government can set (use words such that)

$$
m_{t+1}=m_{t}(1+g), m_{0}=-1 \text {, and } g>r .
$$

In this case, official debt is negative; i.e., the government "runs" a surplus that becomes infinitely large relative to the size of the economy. And because $g>r$, the present value of the time- $t$ surplus as $t$ goes to infinity is infinite.

Alternatively, the government can set (use words such that) $m_{t+1}=m(1+g), m_{0}=1$, and $g>r$. In this case, official debt becomes infinitely large and the present value of government debt at time $t$ as $t$ goes to infinity is infinite. So much for the transversality condition on government debt!

Thus, the government of bankrupt Country X is free to say it's running a balanced budget policy (by saying $m_{t}-0$ for $t \geq 0$ ); a surplus policy, where the surplus becomes enormous relative to the size of the economy; or a debt policy, where the debt becomes enormous relative to the size of the economy. Or it could pick values of the $m_{t} s$ that change sign from one period to the next or, if it likes, on a random basis. In this case, Country X would "run" deficits as well as "surpluses" through time, with no effect whatsoever on the economy or the country's underlying policy.

But no one need listen to the government. Speech, or at least thought, is free. Each citizen of Country X, or of any other country for that matter, can choose her own language (pattern of the $m_{t} \mathrm{~s}$ ) and pronounce publicly or whisper to herself that Country $\mathrm{X}$ is running whatever budgetary policy most strikes her fancy. Citizens schooled on Keynesian economics as well as supply siders, both of whom warm to big deficits, can choose fiscal labels to find fiscal bliss. At the same time, Rockefeller Republicans (are there any left and do they remember Rocky?) can soothe their souls with reports of huge surpluses and fiscal sobriety.

To summarize, countries can go bankrupt, but whether or not they are bankrupt or are going bankrupt can't be discerned from their "debt" policies. "Debt" in economics, like distance and time in physics, is in the eyes (or mouth) of the beholder. $^{2}$

\footnotetext{
2 By economics, I mean neoclassical economics in which neither agents nor economic institutions are affected by language. Kotlikoff (2003) provides a longer treatment of this issue, showing that the vapidity of conventional fiscal language is in no way mitigated by considerations of uncertainty, time consistency, distortions, liquidity constraints, or the voluntary nature of payments to the government.
} 


\section{ECONOMIC MEASUREMENT OF THE U.S. FISCAL CONDITION}

As suggested above, the proper way to consider a country's solvency is to examine the lifetime fiscal burdens facing current and future generations. If these burdens exceed the resources of those generations, get close to doing so, or simply get so high as to preclude their full collection, the country's policy will be unsustainable and can constitute or lead to national bankruptcy.

Does the United States fit this bill? No one knows for sure, but there are strong reasons to believe the United States may be going broke. Consider, for starters, Gokhale and Smetters's (2005) analysis of the country's fiscal gap, which measures the present value difference between all future government expenditures, including servicing official debt, and all future receipts. In calculating the fiscal gap, Gokhale and Smetters use the federal government's arbitrarily labeled receipts and payments. Nevertheless, their calculation of the fiscal gap is label-free because alternative labeling of our nation's fiscal affairs would yield the same fiscal gap. Indeed, determining the fiscal gap is part of generational accounting; the fiscal gap measures the extra burden that would need to be imposed on current or future generations, relative to current policy, to satisfy the government's intertemporal budget constraint.

The Gokhale and Smetters measure of the fiscal gap is a stunning \$65.9 trillion! This figure is more than five times U.S. GDP and almost twice the size of national wealth. One way to wrap one's head around $\$ 65.9$ trillion is to ask what fiscal adjustments are needed to eliminate this red hole. The answers are terrifying. One solution is an immediate and permanent doubling of personal and corporate income taxes. Another is an immediate and permanent two-thirds cut in Social Security and Medicare benefits. A third alternative, were it feasible, would be to immediately and permanently cut all federal discretionary spending by 143 percent.

The Gokhale and Smetters study is an update of an earlier, highly detailed, and extensive U.S. Department of the Treasury fiscal gap analysis commissioned in 2002 by then Treasury Secretary
Paul O'Neill. Smetters, who served as Deputy Assistant Secretary of Economic Policy at the Treasury between 2001 and 2002, recruited Gokhale, then Senior Economic Adviser to the Federal Reserve Bank of Cleveland, to work with him and other Treasury staff on the study. The study took close to a year to organize and complete.

Gokhale and Smetters's \$65.9 trillion fiscalgap calculation relies on the same methodology employed in the original Treasury analysis. Hence, one can legitimately view this figure as our own government's best estimate of its present-value budgetary shortfall. The $\$ 65.9$ trillion gap is all the more alarming because its calculation omits the value of contingent government liabilities and relies on quite optimistic assumptions about increases over time in longevity and federal healthcare expenditures.

Take Medicare and Medicaid spending, for example. Gokhale and Smetters assume that the growth rate in these programs' benefit levels (expenditures per beneficiary at a given age) in the short and medium terms will be only 1 percentage point greater than the growth rate of real wages per worker. In fact, over the past four years, real Medicare benefits per beneficiary grew at an annual rate of 3.51 percent, real Medicaid benefits per beneficiary grew at an annual rate of 2.36 percent, and real weekly wages per worker grew at an annual rate of 0.002 percent. $^{3}$

Medicare and Medicaid's benefit growth over the past four years has actually been relatively modest compared with that in the past. Table 1, taken from Hagist and Kotlikoff (forthcoming), shows real benefit levels in these programs grew at an annual rate of 4.61 percent between 1970 and 2002. This rate is significantly higher than that observed during the same period in Germany, Japan, and the United Kingdom. Given the introduction of the new Medicare prescription drug benefit, which will start paying benefits in 2006, one can expect Medicare benefit growth to increase substantially in the near term.

\footnotetext{
3 See www.cms.hhs.gov/researchers/pubs/datacompendium/2003/ 03pg4.pdf from the Centers for Medicare and Medicaid website and http://a257.g.akamaitech.net/7/257/2422/17feb20051700/ www.gpoaccess.gov/eop/2005/B47.xls from the 2005 Economic Report of the President.
} 


\section{Table 1}

\section{Average Annual Benefit Growth Rates, 1970-2002}

\begin{tabular}{lc} 
Country & Rate (\%) \\
\hline Australia & 3.66 \\
Austria & 3.72 \\
Canada & 2.32 \\
Germany & 3.30 \\
Japan & 3.57 \\
Norway & 5.04 \\
Spain & 4.63 \\
Sweden & 2.35 \\
United Kingdom & 3.46 \\
United States & 4.61 \\
SOURCE: Hagist and Kotlikoff (forthcoming). & \\
\hline
\end{tabular}

How are the Bush administration and Congress planning to deal with the fiscal gap? The answer, apparently, is to make it worse by expanding discretionary spending while taking no direct steps to raise receipts. The costs of hurricanes Katrina and Rita could easily total $\$ 200$ billion over the next few years. And the main goal of the President's tax reform initiative will likely be to eliminate the alternative minimum tax.

This administration's concern with long-term fiscal policy is typified by the way it treated the Treasury's original fiscal gap study. The study was completed in the late fall of 2002 and was slated to appear in the president's 2003 budget to be released in early February 2003. But when Secretary O'Neill was ignominiously fired on December 6, 2002, the study was immediately censored. Indeed, Gokhale and Smetters were told within a few days of O'Neill's firing that the study would not appear in the president's budget. The timing of these events suggests the study itself may explain O'Neill's ouster or at least the timing of his ouster. Publication of the study would, no doubt, have seriously jeopardized the passage of the administration's Medicare drug benefit as well as its third tax cut.

For their part, the Democrats have studiously avoided any public discussion of the country's long-term fiscal problems. Senator Kerry made no serious proposals to reform Social Security, Medicare, or Medicaid during the 2004 presidential campaign. And his Democratic colleagues in Congress have evoked Nancy Reagan's mantra"Just say no!"-in response to the president's repeated urging to come to grips with Social Security's long-term financing problem.

The Democrats, of course, had eight long years under President Clinton to reform our nation's most expensive social insurance programs. Their failure to do so and the Clinton administration's censorship of an Office of Management and Budget generational accounting study, which was slated to appear in the president's 1994 budget, speaks volumes about the Democrats' priorities and their likely future leadership in dealing with our nation's fiscal fiasco.

The fiscal irresponsibility of both political parties has ominous implications for our children and grandchildren. Leaving our $\$ 65.9$ trillion bill for today's and tomorrow's children to pay will roughly double their average lifetime net tax rates (defined as the present value of taxes paid net of transfer payments received divided by the present value of lifetime earnings).

Table 2, taken from Gokhale, Kotlikoff, and Sluchynsky (2003), presents the average lifetime net tax rates now facing couples who are 18 years of age and work full time. The calculations incorporate all major tax and transfer programs and assume that the couples work full time through age 64, experience a 1 percent annual real earnings growth, have children at ages 25 and 27, purchase a house scaled to their earnings, and pay college tuition scaled to their earnings. The table shows that average lifetime net tax rates are already fairly high for middle and high earners, who, of course, pay the vast majority of total taxes.

The table also presents marginal net work tax rates. These are not marginal tax rates on working full time (versus not working at all). They are not marginal net tax rates on working additional hours. They are computed by comparing the present value of additional lifetime spending one can afford from working full time each year from age 18 through age 64 and paying net taxes with the present value of additional lifetime spending 
Table 2

Average Net Full-time Worker Tax Rates

\begin{tabular}{cccc}
$\begin{array}{c}\text { Multiple of } \\
\text { minimum wage }\end{array}$ & $\begin{array}{c}\text { Initial total household } \\
\text { earnings (2002 \$) }\end{array}$ & $\begin{array}{c}\text { Average lifetime } \\
\text { net tax rate (\%) }\end{array}$ & $\begin{array}{c}\text { Marginal net } \\
\text { tax rate (\%) }\end{array}$ \\
\hline 1 & 21,400 & -32.2 & 66.5 \\
1.5 & 32,100 & 14.8 & 80.6 \\
2 & 42,800 & 22.9 & 72.2 \\
3 & 64,300 & 30.1 & 63.0 \\
4 & 85,700 & 34.4 & 59.1 \\
5 & 107,100 & 37.8 & 57.5 \\
6 & 128,500 & 41.0 & 57.5 \\
7 & 150,000 & 42.9 & 57.0 \\
8 & 171,400 & 44.2 & 56.6 \\
10 & 192,800 & 45.1 & 56.1 \\
15 & 214,200 & 45.7 & 55.7 \\
30 & 321,400 & 48.4 & 55.2 \\
40 & 428,500 & 49.6 & 54.7
\end{tabular}

NOTE: Present values are actuarial and assume a 5 percent real discount rate.

SOURCE: Gokhale, Kotlikoff, and Sluchynsky (2003).

one can afford in the absence of any taxes or transfers.

Clearly, these marginal net tax rates are very high, ranging from 54.0 percent to 80.6 percent. The rates are highest for low-income workers. For such workers, working full time can mean the partial or full loss of the earned income tax credit (EITC), Medicaid benefits, housing support, food stamps, and other sources of welfare assistance. Going to work also means paying a combined employer-employee Federal Insurance Contribution Act (FICA) tax of 15.3 percent and, typically, state (Massachusetts, in this case) income taxes and federal income taxes (gross of EITC benefits).

Together with David Rapson, a graduate student at Boston University, I am working to develop comprehensive measures of lifetime marginal net taxes on working additional hours and saving additional dollars. Our early work suggests quite high marginal net taxes on these choices as well.

The point here is that trying to double the average lifetime net tax rates of future generations would entail layering additional highly distortive net taxes on top of a net tax system that is already highly distortive. If work and saving disincentives worsen significantly for the broad middle class, we're likely to see major supply responses of the type that have not yet arisen in this country. In addition, we could see massive emigration. That sounds extreme, but anyone who has visited Uruguay of late would tell you otherwise. Uruguay has very high net tax rates and has lost upward of 500,000 young and middle-aged workers to Spain and other countries in recent years. Many of these émigrés have come and are still coming from the ranks of the nation's best educated citizens.

Given the reluctance of our politicians to raise taxes, cut benefits, or even limit the growth in benefits, the most likely scenario is that the government will start printing money to pay its bills. This could arise in the context of the Federal Reserve "being forced" to buy Treasury bills and 
bonds to reduce interest rates. Specifically, once the financial markets begin to understand the depth and extent of the country's financial insolvency, they will start worrying about inflation and about being paid back in watered-down dollars. This concern will lead them to start dumping their holdings of U.S. Treasuries. In so doing, they'll drive up interest rates, which will lead the Fed to print money to buy up those bonds. The consequence will be more money creation-exactly what the bond traders will have come to fear. This could lead to spiraling expectations of higher inflation, with the process eventuating in hyperinflation.

Yes, this does sound like an extreme scenario given the Fed's supposed independence, our recent history of low inflation, and the fact that the dollar is the world's principal reserve currency. But the United States has experienced high rates of inflation in the past and appears to be running the same type of fiscal policies that engendered hyperinflations in 20 countries over the past century.

\section{INCORPORATING UNCERTAINTY}

The world, of course, is highly uncertain. And the fiscal gap/generational accounting discussed above fails to systematically account for that uncertainty. There are two types of uncertainties that need to be considered in assessing a country's prospects for bankruptcy. The first is uncertainty in the economy's underlying technology and preferences. The second is uncertainty in policy.

Let's take the former first. Specifically, let's return to our two-period model but assume that the economy is closed to international trade. And let's assume that at time 0 the economy appears to be going broke insofar as the government has set a permanent level of $h$ such that the economy will experience a death spiral in the absence of any changes in technology. Thus, $k_{1}=w_{0}-h$, and $w\left(k_{1}\right)<w_{0}$, where $w()$ references the wagegeneration function based on existing technology.

Now suppose there is a chance, with probability $\alpha$, of the economy's technology permanently changing, entailing a new and permanent wagegeneration function, $w^{*}()$, such that $w^{*}\left(k_{1}\right)>w_{0}$. If this event doesn't arise, assume that technology permanently remains in its time-0 configuration. Further assume that $w\left(k_{1}\right)<h$, so that if technology doesn't change, the government will go bankrupt in period 1.

How should an economist observing this economy at time 0 describe its prospects for bankruptcy? One way, indeed, the best way, is to simply repeat the above paragraph; that is, take one's audience through (simulate) the different possible scenarios.

But what about generational accounting? How does the economist compare the lifetime burden facing, for example, workers born in period 1 with their capacity to meet that burden? Well, the burden that the government wants to impose, regardless of the technology, entails taking away $h$ from generation 1 when the generation is young and giving $h$ back to the generation when it's old. Because in the regular (the non *) state the government will, by assumption, do its best by its claimants (the time-1 elderly), generation 1 can expect to hand over all their earnings when young and receive nothing when old (because the capital stock when old will be zero). This is a 100 percent lifetime net tax rate.

In the * state, the lifetime net tax rate will be lower. Suppose it's only 50 percent. Should one then form a weighted average of the 100 percent and 50 percent lifetime net tax rates with weights equal to $(1-\alpha)$ and $\alpha$, respectively? Doing so would generate a high average net tax rate, but one below 100 percent. Reporting that generation 1 faces a high expected net tax rate conveys important information, namely, that the economy is nearing bankruptcy. But citing a figure less than 100 percent may also give the false impression that there is no absolutely fatal scenario.

Note that agents born at time 1 can't trade in a market prior to period 1 in order to value their lifetime wages and lifetime fiscal burdens. If such a contingent claims market existed, there would be market valuations of these variables (but no trades because all cohort members are assumed identical). In this case, we could compare the value of claims to future earnings with the negative value of claims to future net taxes. But again, this comparison might fail to convey what one really wants to say about national bankruptcy, namely, 
the chances it will occur and the policies needed to avoid it. How about uncertainty with respect to future policy? Well, the same considerations just mentioned appear to apply for that case as well.

In my view, the best way for generational accounting to accommodate uncertainty is to establish lifetime fiscal burdens facing future generations under different scenarios about the evolution of the economy and of policy. This will necessarily be partial-equilibrium analysis. But that doesn't mean that the projections used in generational accounting have to be static and assume that neither policy nor economic variables change through time. Instead, one should use general equilibrium models to inform and establish policy projection scenarios to which generational accounting can then be applied.

In thinking about uncertainty and this proposed analysis, one should bear in mind that the goal of long-term fiscal analysis and planning is not to determine whether the government's intertemporal budget constraint is satisfied, per se. We know that no matter what path the economy travels, the government's intertemporal budget constraint will be satisfied on an ex post basis. The manner in which the budget constraint gets satisfied may not be pretty. But economic resources are finite, and the government must and will ultimately make someone pay for what it spends. ${ }^{4}$

Thus, in the case of the United States, one could say that there is no fiscal problem facing the United States because the government's intertemporal budget constraint is balanced once one takes into account that young and future generations will, one way or other, collectively be forced to pay $\$ 65.9$ trillion more than they would have to pay based on current tax and transfer schedules. But the real issue is not whether the constraint is satisfied. The real issue is whether the path the government is taking in the process of satisfying the constraint is, to put it bluntly, morally and economically nuts.

The above point bears on the question of valuing the government's contingent liabilities. The real economic issue with respect to contingent liabilities is the same as that with respect to any

4 This statement assumes that the economy is dynamically efficient. government liability. The real issue is not how to value those liabilities, but rather who will pay them, assuming they end up having to be paid. The economy could operate with perfect statecontingent claims markets so that we could tell precisely the market value of the government's contingent claims and see clearly that the government's budget constraint was satisfied-that the market value of all of the government's statecontingent expenditures were fully covered by the market value of its state-contingent receipts. But this knowledge would not by itself tell us how badly generation $X$ would fare were state $Y$ to eventuate. Pricing risk doesn't eliminate risk. And what we really want to know is not just the price at which, for example, the Pension Benefit Guarantee Corporation can offload its contingent liabilities, but also who will suffer and by how much when the Corporation fails to do so and ends up getting hit with a bill.

\section{CAN IMMIGRATION, PRODUCTIVITY GROWTH, OR CAPITAL DEEPENING SAVE THE DAY?}

Many members of the public as well as officials of the government presume that expanding immigration can cure what they take to be fundamentally a demographic problem. They are wrong on two counts. First, at heart, ours is not a demographic problem. Were there no fiscal policy in place promising, on average, $\$ 21,000$ (and growing!) in Social Security, Medicare, and Medicaid benefits to each American age 65 and older, our having a much larger share of oldsters in the United States would be of little economic concern.

Second, it is mistake to think that immigration can significantly alleviate the nation's fiscal problem. The reality is that immigrants aren't cheap. They require public goods and services. And they become eligible for transfer payments. While most immigrants pay taxes, these taxes barely cover the extra costs they engender. This, at least, is the conclusion reached by Auerbach and Oreopoulos (2000) in a careful generational accounting analysis of this issue. 
A different and more realistic potential cure for our fiscal woes is productivity growth, which is supposed to (i) translate into higher wage growth and (ii) expand tax bases and limit requisite tax hikes. Let's grant that higher rates of productivity growth raise real average wages even though the relationship between the two has been surprisingly weak in recent decades. And let's accept that higher real wages will lead to larger tax bases even though it could lead some workers to cut back on their labor supply or retire early. This isn't enough to ensure that productivity growth raises resources on net. The reason, of course, is that some government expenditures, like Social Security benefits, are explicitly indexed to productivity and others appear to be implicitly indexed.

Take military pay. There's no question but that a rise in general wage levels would require paying commensurately higher wages to our military volunteers. Or consider Medicare benefits. A rise in wage levels can be expected to raise the quality of healthcare received by the work force, which will lead the elderly (or Congress on behalf of the elderly) to push Medicare to provide the same.

Were productivity growth a certain cure for the nation's fiscal problems, the cure would already have occurred. The country, after all, has experienced substantial productivity growth in the postwar period, yet its long-term fiscal condition is worse now than at any time in the past. The limited ability of productivity growth to reduce the implied fiscal burden on young and future generations is documented in Gokhale and Smetters (2003) under the assumption that government discretionary expenditures and transfer payments are indexed to productivity.

But the past linkage of federal expenditures to real incomes need not continue forever. Margaret Thatcher made a clean break in that policy when she moved to adjusting British government-paid pensions to prices rather than wages. Over time, the real level of state pensions has remained relatively stable, while the economy has grown. As a result of this and other policies, Great Britain is close to generational balance; that is, close to a situation in which the lifetime net tax rates on future generations will be no higher than those facing current generations.
Assuming the United States could restrain the growth in its expenditures in light of productivity and real wage advances, is there a reliable source of productivity improvement to be tapped? The answer is yes, and the answer lies with China. China is currently saving over a third of its national income and growing at spectacularly high rates. Even though it remains a developing country, China is saving so much that it's running a current account surplus. Not only is China supplying capital to the rest of the world, it's increasingly doing so via direct investment. For example, China is investing large sums in Iran, Africa, and Eastern Europe. ${ }^{5}$

Although China holds close to a half trillion U.S. dollars in reserves, primarily in U.S. Treasuries, the United States sent a pretty strong message in recent months that it doesn't welcome Chinese direct investment. It did so when it rejected the Chinese National Petroleum Corporation's bid to purchase Unocal, a U.S. energy company. The Chinese voluntarily withdrew their bid for the company. But they did so at the direct request of the White House. The question for the United States is whether China will tire of investing only indirectly in our country and begin to sell its dollar-denominated reserves. Doing so could have spectacularly bad implications for the value of the dollar and the level of U.S. interest rates.

Fear of Chinese investment in the United States seems terribly misplaced. With a national saving rate running at only 2.1 percent-a postwar low-the United States desperately needs foreigners to invest in the country. And the country with the greatest potential for doing so going forward is China. ${ }^{6}$

Fehr, Jokisch, and Kotlikoff (2005) develop a dynamic, life-cycle, general equilibrium model to study China's potential to influence the transition paths of Japan, the United States, and the European Union. Each of these countries/regions is entering a period of rapid and significant aging

\footnotetext{
5 See www.atimes.com/atimes/China/GF04Ad07.html; www.channel4.com/news/special-reports/ special-reports-storypage.jsp?id=310; and http://english.people.com.cn/200409/20/eng20040920_157654.html.

6 The remainder of this section draws heavily on Fehr, Jokisch, and Kotlikoff (2005).
} 
that will require major fiscal adjustments. But the aging of these societies may be a cloud with a silver lining coming, in this case, in the form of capital deepening that will raise real wages.

In a previous model that excluded China (Fehr, Jokisch, and Kotlikoff, 2004), my coauthors and I predicted that the tax hikes needed to pay benefits along the developed world's demographic transition would lead to a major capital shortage, reducing real wages per unit of human capital by one-fifth over time. A recalibration of our original model that treats government purchases of capital goods as investment rather than current consumption suggests this concern was overstated. With government investment included, we find much less crowding-out over the course of the century and only a 4 percent long-run decline in real wages. One can argue both ways about the true capital-goods content of much of government investment, so we don't view the original findings as wrong, just different.

Adding China to the model further alters, indeed, dramatically alters, the model's predictions. Even though China is aging rapidly, its saving behavior, growth rate, and fiscal policies are currently very different from those of developed countries. If successive Chinese cohorts continue to save like current cohorts, if the Chinese government can restrain growth in expenditures, and if Chinese technology and education levels ultimately catch up with those of the West and Japan, the model looks much brighter in the long run. China eventually becomes the world's saver and, thereby, the developed world's savior with respect to its long-run supply of capital and long-run general equilibrium prospects. And, rather than seeing the real wage per unit of human capital fall, the West and Japan see it rise by one-fifth by 2030 and by three-fifths by 2100 . These wage increases are over and above those associated with technical progress, which we model as increasing the human capital endowments of successive cohorts.

Even if the Chinese saving behavior (captured by its time-preference rate) gradually approaches that of Americans, developed-world real wages per unit of human capital are roughly 17 percent higher in 2030 and 4 percent higher at the end of the century. Without China they'd be only 2 percent higher in 2030 and, as mentioned, 4 percent lower at the end of the century.

What's more, the major outflow of the developed world's capital to China predicted in the short run by our model does not come at the cost of lower wages in the developed world. The reason is that the knowledge that their future wages will be higher (thanks to China's future capital accumulation) leads our model's workers to cut back on their current labor supply. So the short-run outflow of capital to China is met with a commensurate short-run reduction in developed-world labor supply, leaving the short-run ratio of physical capital to human capital, on which wages positively depend, actually somewhat higher than would otherwise be the case.

Our model does not capture the endogenous determination of skill premiums studied by Heckman, Lochner, and Taber (1996) or include the product of low-skill-intensive products. Doing so could well show that trade with China, at least in the short run, explains much of the relative decline in the wages of low-skilled workers in the developed world. Hence, we don't mean to suggest here that all United States, European Union, and Japanese workers are being helped by trade with China, but rather that trade with China is, on average, raising the wages of developed-world workers and will continue to do so.

The notion that China, India, and other developing countries will alleviate the developedworld's demographic problems has been stressed by Siegel (2005). Our paper, although it includes only one developing country-China-supports Siegel's optimistic long-term macroeconomic view. On the other hand, our findings about the developed world's fiscal condition remain troubling. Even under the most favorable macroeconomic scenario, tax rates still rise dramatically over time in the developed world to pay baby boomers their government-promised pension and health benefits. However, under the best-case scenario, in which long-run wages are 65 percent higher, the U.S. payroll tax rates are roughly 40 percent lower than they would otherwise be. This result rests on the assumption that, while Social Security benefits are increased in light of 
the Chinese-investment-induced higher real wages, federal government healthcare benefits are not; that is, the long-run reduction in payroll tax rates is predicated on outgrowing a significant share of our healthcare-expenditure problems.

\section{FIXING OUR FISCAL INSTITUTIONS ${ }^{7}$}

Determining whether a country is already bankrupt or going bankrupt is a judgment call. In my view, our country has only a small window to address our problems before the financial markets will do it for us. Yes, there are ways out of our fiscal morass, including Chinese investment and somehow getting a lid on Medicare and Medicaid spending, but I think immediate and fundamental reform is needed to confidently secure our children's future.

The three proposals I recommend cover taxes, Social Security, and healthcare and are interconnected and interdependent. In particular, tax reform provides the funding needed to finance Social Security and healthcare reform. It also ensures that the rich and middle class elderly pay their fair share in resolving our fiscal gap.

\section{Tax Reform}

The plan here is to replace the personal income tax, the corporate income tax, the payroll (FICA) tax, and the estate and gift tax with a federal retail sales tax plus a rebate. The rebate would be paid monthly to households, based on the household's demographic composition, and would be equal to the sales taxes paid, on average, by households at the federal poverty line with the same demographics.

The proposed sales tax has three highly progressive elements. First, thanks to the rebate, poor households would pay no sales taxes in net terms. Second, the reform would eliminate the highly regressive FICA tax, which is levied only on the first $\$ 90,000$ of earnings. Third, the sales tax would effectively tax wealth as well as wages, because when the rich spent their wealth and when

7 This section draws heavily from Ferguson and Kotlikoff (2005). workers spent their wages, they would both pay sales taxes.

The single, flat-rate sales tax would pay for all federal expenditures. The tax would be highly transparent and efficient. It would save hundreds of billions of dollars in tax compliance costs. And it would either reduce or significantly reduce effective marginal taxes facing most Americans when they work and save.

The sales tax would also enhance generational equity by asking rich and middle class older Americans to pay taxes when they spend their wealth. The poor elderly, living on Social Security, would end up better off. They would receive the sales tax rebate even though the purchasing power of their Social Security benefits would remain unchanged (thanks to the automatic adjustment to the consumer price index that would raise their Social Security benefits to account for the increase in the retail-price level).

The sales tax would be levied on all final consumption goods and services and would be set at 33 percent-high enough to cover the costs of this "New New Deal's" Social Security and healthcare reforms as well as meet the government's other spending needs. On a tax-inclusive basis, this is a 25 percent tax rate, which is a lower or much lower marginal rate than most workers pay on their labor supply. The marginal tax on saving under the sales tax would be zero, which is dramatically lower than the effective rate now facing most savers.

\section{Social Security Reform}

My second proposed reform deals with Social Security. I propose shutting down the retirement portion of the current Social Security system at the margin by paying in the future only those retirement benefits that were accrued as of the time of the reform. This means that current retirees would receive their full benefits, but current workers would receive benefits based only on their covered wages prior to the date of the reform. The retail sales tax would pay off all accrued retirement benefits, which eventually would equal zero. The current Social Security survivor and disability programs would remain unchanged except that their benefits would be paid by the sales tax. 
In place of the existing Social Security retirement system, I would establish the Personal Security System (PSS)—a system of individual accounts, but one with very different properties from the scheme proposed by the president. All workers would be required to contribute 7.15 percent of their wages up to what is now the earnings ceiling covered by Social Security (i.e., they'd contribute what is now the employee FICA payment) into an individual PSS account. Married or legally partnered couples would share contributions so that each spouse/partner would receive the same contribution to his or her account. The government would contribute to the accounts of the unemployed and disabled. In addition, the government would make matching contributions on a progressive basis to workers' accounts, thereby helping the poor to save.

All PSS accounts would be private property. But they would be administered and invested by the Social Security Administration in a marketweighted global index fund of stocks, bonds, and real-estate securities. Consequently, everyone would have the same portfolio and receive the same rate of return. The government would guarantee that, at retirement, the account balance would equal at least what the worker had contributed, adjusted for inflation; that is, the government would guarantee that workers could not lose what they contributed. This would protect workers from the inevitable downside risks of investing in capital markets.

Between ages 57 and 67, account balances would be gradually sold off each day by the Social Security Administration and exchanged for inflation-protected annuities that would begin paying out at age 62. By age 67, workers' account balances would be fully annuitized. Workers who died prior to age 67 would bequeath their account balances to their spouses/partners or children. Consequently, low-income households, whose members die at younger ages than those of highincome households, would be better protected. Finally, under this reform, neither Wall Street nor the insurance industry would get their hands on workers' money. There would be no loads, no commissions, and no fees.

\section{Healthcare Reform}

My final proposed reform deals not just with our public healthcare programs, Medicare and Medicaid, but with our private health-insurance system as well. That system, as is well known, leaves some 45 million Americans uninsured. My reform would abolish the existing fee-for-service Medicare and Medicaid programs and enroll all Americans in a universal health-insurance system called the Medical Security System (MSS). In October of each year, the MSS would provide each American with an individual-specific voucher to be used to purchase health insurance for the following calendar year. The size of the voucher would depend on the recipients' expected health expenditures over the calendar year. Thus, a 75 year old with colon cancer would receive a very large voucher, say $\$ 150,000$, whereas a healthy 30 year old might receive a $\$ 3,500$ voucher.

The MSS would have access to all medical records concerning each American and set the voucher level each year based on that information. Those concerned about privacy should rest easy. The government already knows about millions of Medicare and Medicaid participants' health conditions because it's paying their medical bills. This information has never, to my knowledge, been inappropriately disclosed.

The vouchers would pay for basic in- and outpatient medical care, prescription medications, and long-term care over the course of the year. If you ended up costing the insurance company more than the amount of your voucher, the insurance company would make up the difference. If you ended up costing the company less than the voucher, the company would pocket the difference. Insurers would be free to market additional services at additional costs. The MSS would, at long last, promote healthy competition in the insurance market, which would go a long way to restraining healthcare costs.

The beauty of this plan is that all Americans would receive healthcare coverage and that the government could limit its total voucher expenditure to what the nation could afford. Unlike the current fee-for-service system, under which the government has no control of the bills it receives, 
the MSS would explicitly limit the government's liability.

The plan is also progressive. The poor, who are more prone to illness than the rich, would receive higher vouchers, on average, than the rich. And, because we would be eliminating the current income-tax system, all the tax breaks going to the rich in the form of non-taxed health-insurance premium payments would vanish. Added together, the elimination of this roughly $\$ 150$ billion of tax expenditures, the reduction in the costs of hospital emergency rooms (which are currently subsidized out of the federal budget), and the abolition of the huge subsidies to insurers in the recent Medicare drug bill would provide a large part of the additional funding needed for the MSS to cover the entire population.

\section{Eliminating the Fiscal Gap}

A 33 percent federal retail-sales tax rate would generate federal revenue equal to 21 percent of GDP - the same figure that prevailed in 2000. Currently, federal revenues equal 16 percent of GDP. So we are talking here about a major tax hike. But we're also talking about some major spending cuts. First, Social Security would be paying only its accrued benefits over time, which is trillions of dollars less than its projected benefits, when measured in present value. Second, we would be putting a lid on the growth of healthcare expenditures. Limiting excessive growth in these expenditures will, over time, make up for the initial increase in federal healthcare spending arising from the move to universal coverage. Third, we'd reduce federal discretionary spending by one-fifth and, thereby, return to the 2000 ratio of this spending to GDP. Taken together, these very significant tax hikes and spending cuts would, I believe, eliminate most if not all of our nation's fiscal gap.

\section{CONCLUSION}

There are 77 million baby boomers now ranging from age 41 to age 59. All are hoping to collect tens of thousands of dollars in pension and healthcare benefits from the next generation. These claimants aren't going away. In three years, the oldest boomers will be eligible for early Social Security benefits. In six years, the boomer vanguard will start collecting Medicare. Our nation has done nothing to prepare for this onslaught of obligation. Instead, it has continued to focus on a completely meaningless fiscal metric- "the" federal deficit—censored and studiously ignored long-term fiscal analyses that are scientifically coherent, and dramatically expanded the benefit levels being explicitly or implicitly promised to the baby boomers.

Countries can and do go bankrupt. The United States, with its $\$ 65.9$ trillion fiscal gap, seems clearly headed down that path. The country needs to stop shooting itself in the foot. It needs to adopt generational accounting as its standard method of budgeting and fiscal analysis, and it needs to adopt fundamental tax, Social Security, and healthcare reforms that will redeem our children's future.

\section{REFERENCES}

Auerbach, Alan and Oreopoulos, Philip. "The Fiscal Effects of U.S. Immigration: A Generational Accounting Perspective," in James Poterba, ed., Tax Policy and the Economy. Volume 14. Cambridge, MA: MIT Press, 2000, pp. 23-56.

Fehr, Hans; Jokisch, Sabine and Kotlikoff, Laurence J. "The Role of Immigration in Dealing with the Developed World's Demographic Dilemma." FinanzArchiv, September 2004, 60(3), pp. 296-324.

Fehr, Hans; Jokisch, Sabine and Kotlikoff, Laurence J. "Will China Eat Our Lunch or Take Us to Dinner? Simulating the Transition Paths of the U.S., the EU, Japan, and China." NBER Working Paper No. 11668, National Bureau of Economic Research, October 2005.

Ferguson, Niall and Kotlikoff, Laurence J. "Benefits Without Bankruptcy-The New New Deal." The New Republic, August 15, 2005.

Gokhale, Jagadeesh and Smetters, Kent. "Measuring Social Security's Financial Problems.” NBER Working Paper No. 11060, National Bureau of Economic Research, January 2005. 
Gokhale, Jagadeesh and Smetters, Kent. Fiscal and Generational Imbalances: New Budget Measures for New Budget Priorities. Washington, DC: The American Enterprise Press, 2003.

Gokhale, Jagadeesh; Kotlikoff, Laurence J. and Sluchynsky, Alexi. "Does It Pay to Work?"

Unpublished manuscript, January 2003.

Hagist, Christian and Kotlikoff, Laurence J. “Who's Going Broke?: Comparing Healthcare Costs in Ten OECD Countries.” Milken Institute Review (forthcoming).

Heckman, James; Lochner, Lance and Taber, Christopher. "Explaining Rising Wage Inequality: Explanations with a Dynamic General Equilibrium Model of Labor Earnings with Heterogeneous Agents." Review of Economic Dynamics, January, 1998, 1(1), pp. 1-58.

Kotlikoff, Laurence J. Generational Policy. Cambridge, MA: MIT Press, 2003.

Siegel, Jeremy J. The Future for Investors: Why the Tried and the True Triumph Over the Bold and the New. New York, NY: Crown Publishing Group, 2005. 
